\title{
THE EFFECT OF POT SIZE AND TRANSPLANT AGE ON THE YIELD AND QUALITY OF WHITE, GREEN AND ROMANESCO CAULIFLOWER CURDS
}

\author{
Stanisław CEBULA \\ Department of Vegetable Crops, Agricultural University in Krakow \\ 29 Listopada 54, 31-425 Kraków, Poland
}

Received: March 12, 2009; Accepted: June 3, 2009

\begin{abstract}
Summary
The subject of the experiment were three cultivars representing three different kinds of cauliflower: white ('Planita $F_{1}{ }^{\prime}$ ), green ('Trevi $F_{1}{ }^{\prime}$ ) and romanesco ('Amfora $\mathrm{F}_{1}{ }^{\prime}$ ). All plants were cultivated from transplants of various age (ca. 30 and 40 days) prepared in different size pots (96 and 160 cells/tray). The parameters of transplants ready for planting were determined and the yield level as well as commercial quality of curds was assessed. The fresh mass of overground part and root system of transplants of all cauliflower types was higher in case of older transplants and transplants grown in pots of larger cell volume. The commercial yield and the average curd weight were highest for white cauliflower cultivar, lower for green cultivar and the lowest for the romanesco type variety. All three cauliflower varieties reached their maximal values in this respect with the older-transplant and larger pot size. Most curds of grade I and the biggest diameter were formed in case of white cauliflower plants, slightly fewer of green variety and the least of the romanesco type. In case of all cauliflower varieties plants cultivated from older transplants had a larger root system, which ensured the best quality and most favourable marketable curds. Particular cauliflower types differed quite considerably in respect to their tendency to form curd defects (green bracts, hollow stem, riciness and browning). White cauliflower was the least susceptible to disorder in curd formation with the romanesco being the most sensitive type. In case of white cauliflower, transplants obtained from smaller pots, particularly in the case of younger transplants, resulted in the increased number of defects. However, in case of green and romanesco forms transplants produced in larger pots resulted in the occurrence of higher number of curd defects, particularly for older transplants.
\end{abstract}

key words: cauliflower type, transplant age, cell volume, yield, curd quality

Corresponding author: e-mail: scebula@gr.ar.krakow.pl (C) Copyright by RIVC 


\section{INTRODUCTION}

The manner of transplant production is of considerable importance in cauliflower cultivation. Cauliflower, to a much higher degree than other vegetable species, strongly reacts to transplant condition, the fact which is manifested in yield quantity and curd quality. In transplant production, the size of pots used as well as the time of production are crucial and play an important role in the final condition of plants (Godoy \& Cardoso 2005).

The tendency to decrease the cell volume in trays during vegetable production has been observed for a long time. The use of smaller pots allows to obtain more plants from the same unit area. In effect, the cultivation area is used more effectively, the amount of substrate can be decreased and, in consequence, production costs go down (NeSmith \& Duval 1998). However, diminishing the pot size may lead to root system growth reduction and, in effect, to a weaker development of the overground transplant mass, which may negatively influence the further plant growth following planting in the field (Booij 1990, Wiebe 1981).

On the other hand, adequate transplant age ensures continuous and uniform growth of plants after planting, which results in the higher effectiveness and the yield quality. Occasionally, during early spring cultivation there is a necessity to extend the transplant production period due to unfavourable weather conditions, however in autumn transplants should be planted at their optimal development phase. Planting older transplants shortens the vegetative growth period of plants in the field and accelerates the plant's entering the phase of generative initiation which does not always favour the right curd development (Lewandowska 1992, Wurr et al. 1986). In case of age-advanced cauliflower transplants it may influence curd future growth more negatively (Vavrina 1998), than in case of closely related species - broccoli (Damato et. al. 1994, Lamont 1992).

All the aspects mentioned above have been widely discussed in the literature in regard to white curd cauliflower, however the knowledge regarding green and romanesco cultivars is still very scarce.

The purpose of these experiments was to determine the effect of manner transplant production in respect to pot size and transplant age and the internal relations between these factors on the yield and marketable quality of curds on all three types of cauliflower.

\section{MATERIAL AND METHODS}

The field research was carried out at the Mydlniki Research Station of the Agricultural University in Krakow in 2002-2004. The subjects of experiments were three types of cauliflower: white (Planita $F_{1}$ ), green (Trevi $F_{1}$ ) and romanesco (Amfora $F_{1}$ ), cultivated from transplants of various age prepared in different size pots. Seeds were sown on two different dates: at the end of the second and in the third decade of May, at 10 days intervals, to 42 x $42 \mathrm{~mm}$ (96 cells/tray) and $32 \times 32 \mathrm{~mm}$ multipots (160 cells/tray) filled with peat substrate. 
The peat $\mathrm{pH}$ was at the level of 6.5 and was fertilized with the mix of MIS-4 in the amount of $3.5 \mathrm{~kg}$ of the part containing macroelements and $135 \mathrm{~g}$ microelements for $1 \mathrm{~m}^{2}$ of the substrate. During the production period transplants were fertilized two or three times with $0.1 \%$ water solution of multicomponent fertilizer (Superba brown), starting fertilization at 15 days prior to planting. Transplants produced in nursery-greenhouse were systematically watered when necessary. At the time of planting in the field cauliflower transplants were ca. 30 and 40 days old. Prior to planting in the field the fresh and dry matter of the overground part and transplant root system were determined. At that time, growth parameters were assessed based on the measurements carried out on 6 plants selected from every experimental object.

The transplants were planted in the field at $67.5 \times 50 \mathrm{~cm}$ spacing in the last decade of June. The 3-factor experiment (cauliflower forms, seedling age and pot size) was established in a randomized block design, with four replicates. The size of the experimental plot was as follows: $2.70 \mathrm{~m}$ (4 rows of plants) $\times$ $3.50 \mathrm{~m}$ (7 plants $)=9.45 \mathrm{~m}^{2}$ (the total plot size). In total, there were 28 plants on each experimental plot of which four edge plants constituted protective belts and measurements were carried out on 24 plants (harvest plot $=8.10 \mathrm{~m}^{2}$ ).

During vegetation period treatment procedures were performed (weed and pest control, fertilization, watering, curd protection against the sun) according to recommendations for this species.

Curds were harvested systematically, usually twice a week, starting from the end of August and throughout September and October. At each harvest time the yield was determined taking into account the mass and the number of curds. Additionally, their commercial value was assessed. In the analysis the share of particular grades was taken into consideration (I, II and unmarketable) in total yield and curd size class in marketable yield, defined as the diameter measured along the arch (A > $30 \mathrm{~cm}$, B 25-30 cm, C 20-25 cm, D 15-20 cm). Furthermore, all defects in curds were assessed, i.e. green bracts, riciness, hollow stem and browning. During harvest both cauliflower curds quality and curd size were taken into account so it was possible to place six heads in a universal plastic box, which is a standard packaging in trade.

The finale results are presented as means for three years of trials due to the fact that obtained dependences were very close in particular years. Statistical evaluation was executed using analysis of variance (Duncan test) at $\mathrm{P}=0.95$.

\section{RESULTS AND DISCUSSION}

At the time of planting in the field the fresh mass of the overground part of the transplant for all types of cauliflower depended on its age and was almost two times higher in the case of older transplants as compared to the younger ones (Table 1). It was also higher in the case of larger pots. Fresh mass of root system, similarly to overground part, depended on transplant age and pot size without any of these factors being a dominant one. However, dry matter content both in green parts and in roots was slightly higher for plants obtained from 
smaller pots. On the other hand, a longer production time increased dry matter content in overground part and decreased in the underground one.

Table 1. Fresh weight and dry matter content in over-ground parts and roots of cauliflower transplants

\begin{tabular}{cccccccc}
\hline \multirow{2}{*}{$\begin{array}{c}\text { Type of } \\
\text { cauliflower }\end{array}$} & $\begin{array}{c}\text { Kind of } \\
\text { transplants }\end{array}$ & \multicolumn{2}{c}{ Fresh weight $\left(\mathrm{g} \cdot\right.$ plant $\left.^{-1}\right)$} & \multicolumn{3}{c}{ Dry matter (\%) } \\
\cline { 3 - 8 } & $\begin{array}{c}\text { Over- } \\
\text { ground } \\
\text { parts }\end{array}$ & Roots & Total & $\begin{array}{c}\text { Over- } \\
\text { ground } \\
\text { parts }\end{array}$ & Roots & Mean \\
\hline \multirow{5}{*}{ White } & $30 / 96^{*}$ & 2.84 & 0.39 & 3.23 & 13.56 & 21.58 & 17.57 \\
& $30 / 160$ & 1.64 & 0.22 & 1.86 & 14.46 & 23.84 & 19.15 \\
& $40 / 96$ & 5.72 & 0.60 & 6.32 & 13.96 & 17.10 & 15.53 \\
Green & $40 / 160$ & 3.16 & 0.38 & 3.54 & 15.87 & 19.16 & 17.52 \\
\hline \multirow{5}{*}{ Romanesco } & $30 / 96$ & 2.49 & 0.32 & 2.81 & 12.48 & 19.10 & 15.79 \\
& $30 / 160$ & 1.65 & 0.31 & 1.96 & 13.62 & 20.32 & 16.97 \\
& $40 / 96$ & 5.85 & 0.85 & 6.70 & 14.09 & 18.64 & 16.37 \\
& $40 / 160$ & 2.78 & 0.42 & 3.20 & 14.56 & 19.18 & 16.87 \\
\hline & $30 / 96$ & 3.46 & 0.59 & 4.05 & 12.40 & 17.99 & 15.20 \\
& $40 / 96$ & 2.38 & 0.33 & 2.71 & 11.61 & 26.21 & 18.91 \\
& $40 / 160$ & 4.38 & 0.58 & 6.05 & 13.14 & 17.57 & 15.36 \\
& & 0.58 & 4.96 & 14.28 & 26.74 & 20.51 \\
\hline
\end{tabular}

* Note: first numerals means age of transplants and the second one number of cells per tray

The extension of transplant production time by ten days resulted in the increase of both the green mass and the root system. This is a well known effect of summing up daily biomass increases, i.e. the function of time, the fact also confirmed by other authors (Vavrina 1998). However, demonstrating more vigorous transplant growth in larger pots is justified simply by more favourable conditions of plants development (more substrate, better water and nutrients availability), which, in case of smaller pots could be a limiting factor (NeSmith \& Duval 1998, Wiebe 1981). Such an explanation can also be confirmed by results of dry matter content in both transplant parts which was higher in larger pots. However, it needs to be stressed that results presented in this study, even though repetitive in three consecutive years were obtained based on measurements carried out on small transplant population and did not allow to perform the statistical analysis. Therefore, they should be deemed rather as characteristics of ready to planting seedlings than a comparison of research objects.

Commercial yield measured in $\mathrm{t} \cdot \mathrm{ha}^{-1}$ was the highest in case of white cauliflower type and its value ranged from 28.80 to $36.52 \mathrm{t}^{\mathrm{t}} \mathrm{ha}^{-1}$, lower in case of green type (26.11-30.28 tha $\left.\mathrm{ha}^{-1}\right)$ and the lowest for romanesco $\left(16.31-23.71 \mathrm{t} \cdot \mathrm{ha}^{-1}\right)$ (Table 2). All three varieties of cauliflower achieved their maximum yields in case of older transplants and the larger pot size. Similar dependence was also observed for average curd weight, which in case of white variety ranged from $1.36-1.53 \mathrm{~kg}$, for green variety from $0.97-1.16 \mathrm{~kg}$ and in case of romanesco type variety it was between $0.86-0.96 \mathrm{~kg}$. However, it was difficult to observe 
such a trend in case of the number of marketable cauliflower curds from one unit of study area.

Table 2. Marketable yield and mean weight of cauliflower curds

\begin{tabular}{ccccc}
\hline \multirow{2}{*}{$\begin{array}{c}\text { Type of cauli- } \\
\text { flower }\end{array}$} & $\begin{array}{c}\text { Kind of } \\
\text { transplants }\end{array}$ & \multicolumn{2}{c}{ Marketable yield } & Mean weight \\
\cline { 2 - 4 }$\cdot \mathrm{ha}^{-1}$ & number $\cdot \mathrm{ha}^{-1}$ & of curds $\mathrm{kg})$ \\
\hline \multirow{4}{*}{ White } & $30 / 96^{*}$ & $28.80 \mathrm{efg} * *$ & $20678 \mathrm{abc}$ & $1.40 \mathrm{e}$ \\
& $30 / 160$ & $31.05 \mathrm{~g}$ & $22015 \mathrm{bcd}$ & $1.41 \mathrm{e}$ \\
& $40 / 96$ & $36.52 \mathrm{~h}$ & $23865 \mathrm{def}$ & $1.53 \mathrm{f}$ \\
Green & $40 / 160$ & $30.72 \mathrm{fg}$ & $22633 \mathrm{cde}$ & $1.36 \mathrm{e}$ \\
\hline \multirow{5}{*}{ Romanesco } & $30 / 96$ & $29.52 \mathrm{efg}$ & $26128 \mathrm{fg}$ & $1.13 \mathrm{~d}$ \\
& $30 / 160$ & $26.11 \mathrm{de}$ & $26853 \mathrm{~g}$ & $0.97 \mathrm{bc}$ \\
& $40 / 96$ & $30.28 \mathrm{fg}$ & $26128 \mathrm{fg}$ & $1.16 \mathrm{~d}$ \\
& $40 / 160$ & $27.35 \mathrm{ef}$ & $27058 \mathrm{~g}$ & $1.01 \mathrm{c}$ \\
\hline & $30 / 96$ & $21.68 \mathrm{bc}$ & $22765 \mathrm{cde}$ & $0.95 \mathrm{bc}$ \\
& $30 / 160$ & $16.31 \mathrm{a}$ & $19088 \mathrm{a}$ & $0.86 \mathrm{a}$ \\
& $40 / 96$ & $23.71 \mathrm{~cd}$ & $24588 \mathrm{efg}$ & $0.96 \mathrm{bc}$ \\
\hline
\end{tabular}

* Note: See Table 1

Note: Values in columns marked with the same letter do not differ significantly at $\mathrm{P}=0.05$

The highest share of grade I in total yield was obtained for white cauliflower variety (90.4-93.3\%), slightly lower for green type variety (85.2-91.4\%) and significantly lower for romanesco variety (75.7-82.3\%) (Fig.1). Similar results were obtained when three cauliflower types were compared in respect to curd size measured along the arch, with the domination of white cultivar over the other two being more evident (Fig. 2). Thus, most valuable curds of class A were found in case of white cauliflower where the value ranged from 82.7 to $93.8 \%$, with $75.5-85.3 \%$ for the green variety and $73.7-87.6 \%$ for the romanesco type. It is interesting that for all three types of cauliflower, plants cultivated from older transplants with bigger root system resulted in high marketable value curds.

A transplants with well developed strong root system, are probably much better prepared for a stress connected with planting in the field and such plants usually produce and higher quality marketable curds. This trend was observed for all three cauliflower varieties and is consistent with the results obtained by other authors (Booij 1990, Godoy \& Cardoso 2005, Wurr et al. 1986). However, some discrepancies of particular authors findings exist in this aspect. Lewandowska (1992) claims that younger transplants give higher yield, however in that particular case this might be a result of higher age differentiation (3-7 weeks) than in presented experiments. It seems that searching for cost cuts (using smaller pots, shortening production period) at the stage of transplant production does not deserve recommendation. 

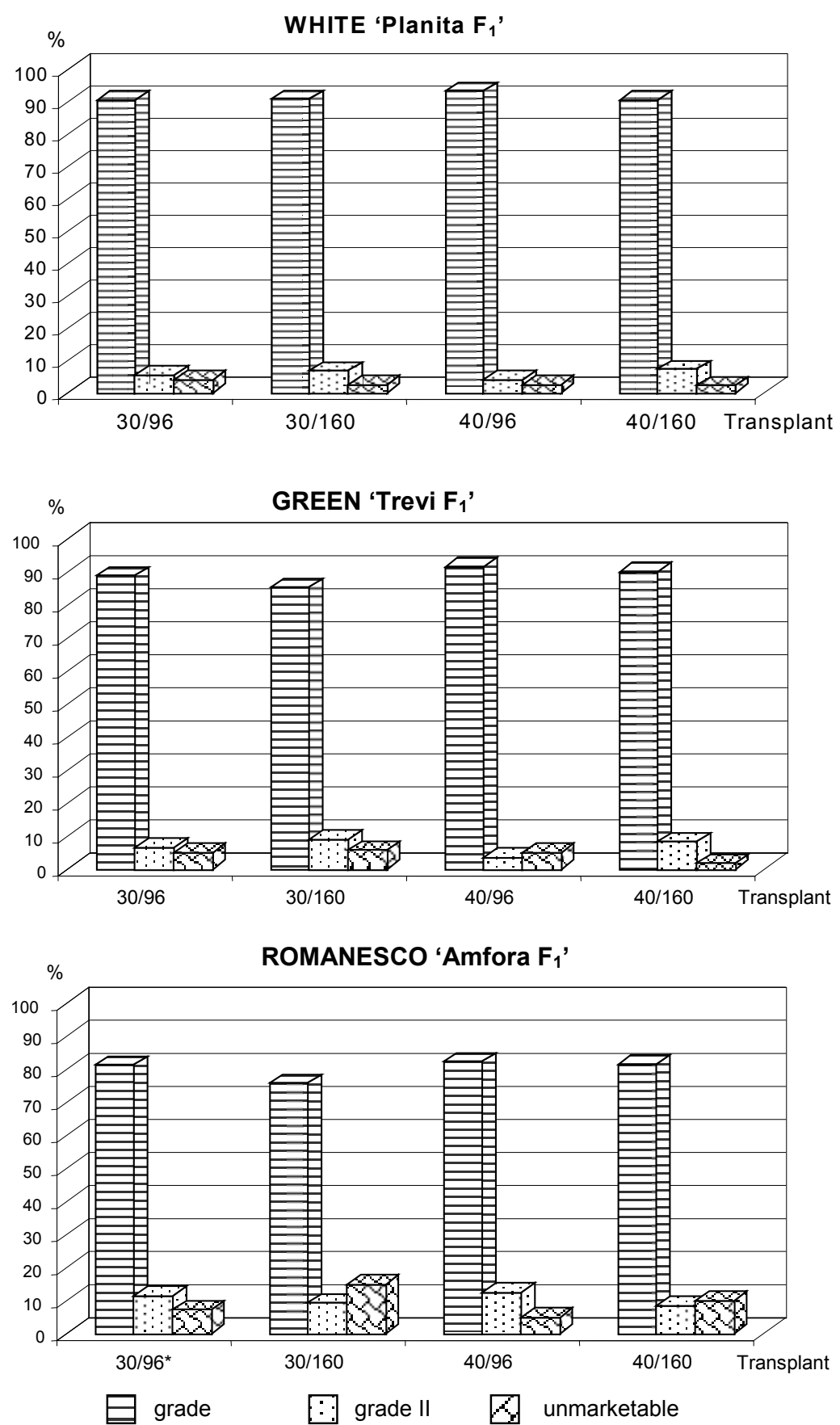

* Note: See Table 1

Fig. 1. Structure of cauliflower yield ( $\%$ of total number of curds) 

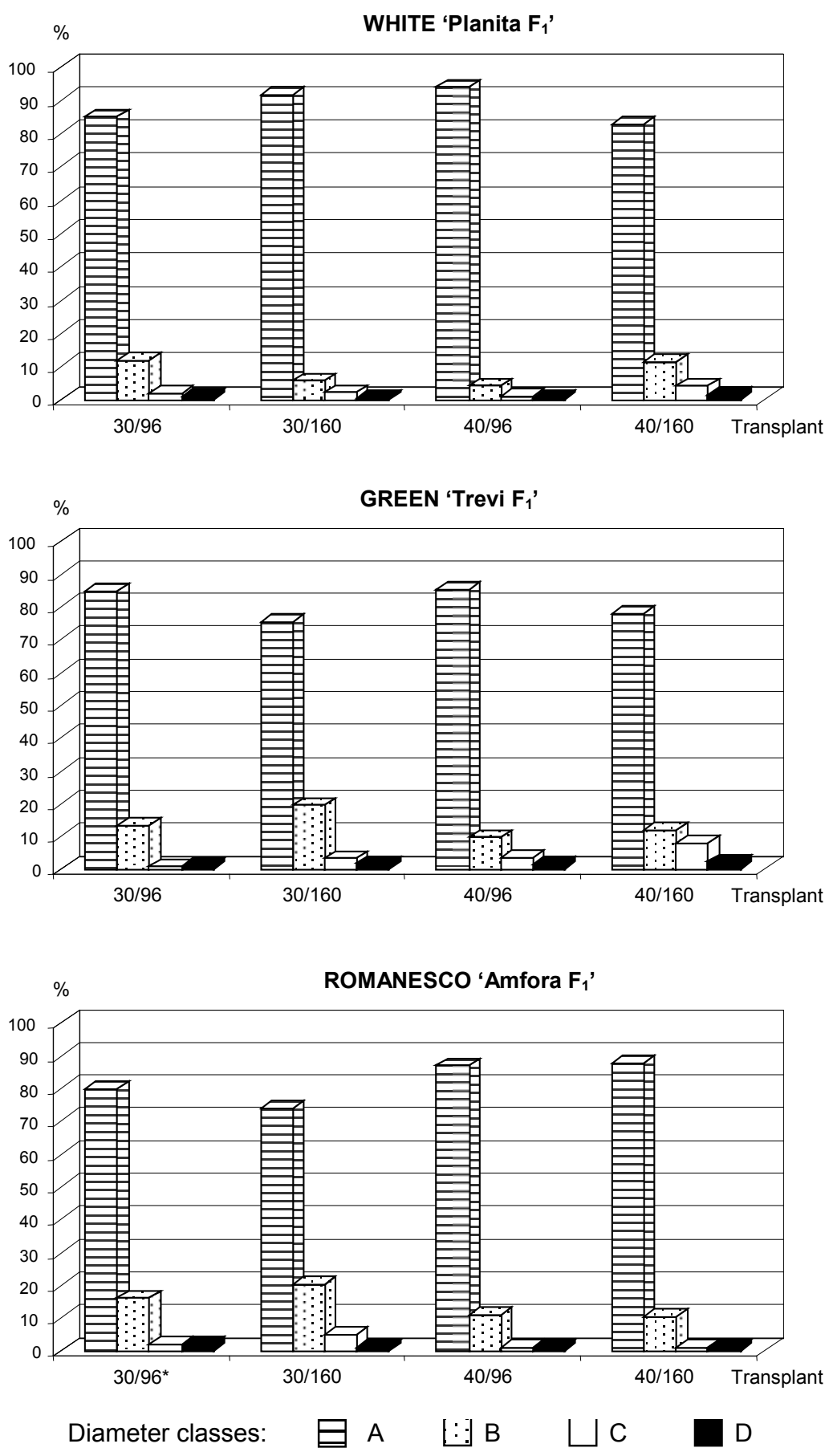

* Note: See Table 1

Fig. 2. Diameter classes of cauliflower curds ( $\%$ of total number of curds) 
Particular cauliflower types differed considerably in respect to disorder in curd formation (Fig. 3). Generally, white cauliflower was the most resistant to curd defect formation and romanesco was the most sensitive type. As far as types of defects are concerned, browning and riciness were the most rare, whilst green bracts occurred more often and hollow stems where the most popular. Defects were diversified between particular varieties. In case of white variety green bracts were the most common and other defects appeared less often. Green cauliflower was the type where green bracts and hollow stems were the most common defects. However, in case of romanesco type cauliflower even more than $30 \%$ of curds were affected with hollow stems, several times more than with green bracts. A relationship between the transplant age and the manner in which it was produced and the scale of curd deformation occurrence was observed during conducted experiments. It differed between particular cauliflower types. In case of white cauliflower the transplants obtained from smaller pots caused the increase in the number of defects, the fact that particularly affected younger transplants. Fewest defects were observed in case of older transplants with better developed root system. The reaction was contrary for green and romanesco type cauliflowers, namely the transplants cultivated in larger pots had more curd defects, which concerned mostly older transplants.

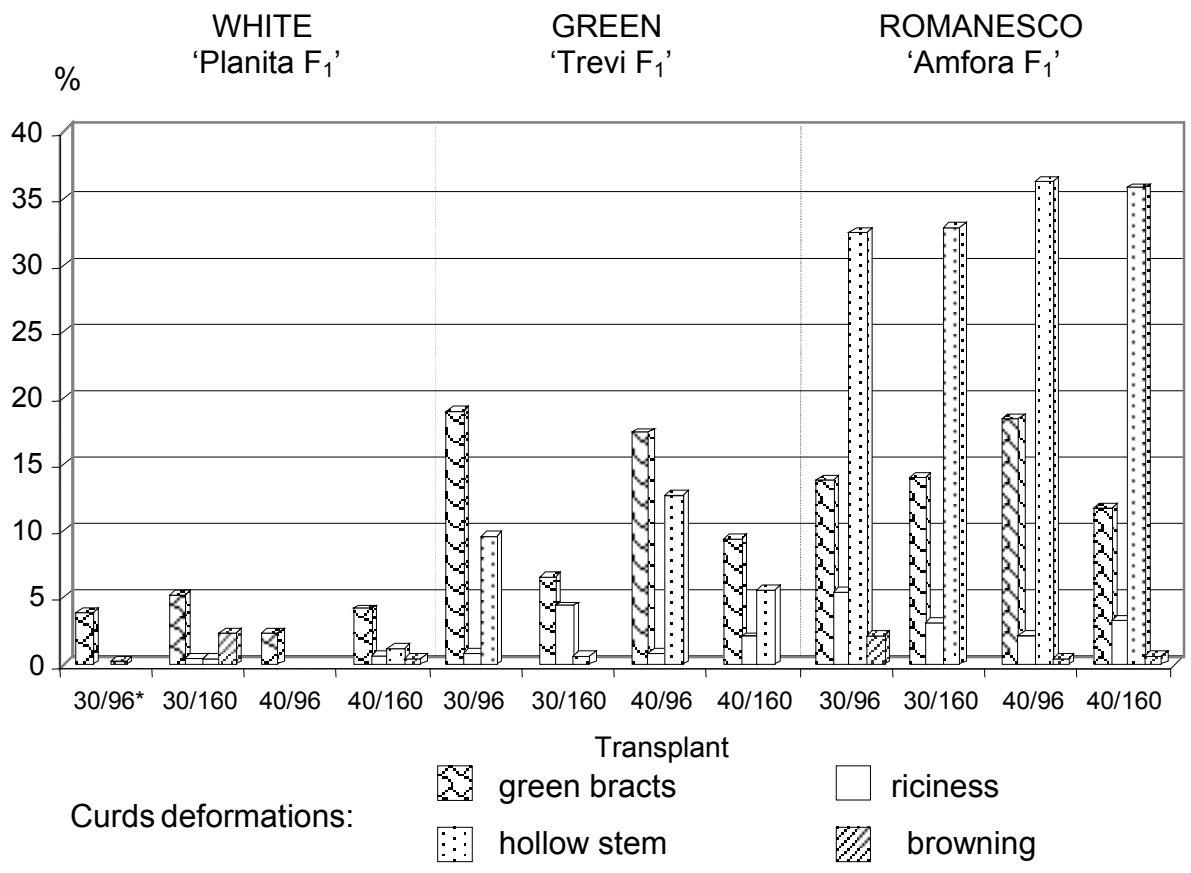

* Note: See Table 1

Fig. 3. Disorder in cauliflower curd formation ( $\%$ of total number of curds) 
Most of described curd defects are caused by variable thermal conditions, usually excessively high or low temperatures at certain growth periods (Grevsen \& Olesen 1994, Grevsen et al. 2003), but sometimes also by mistakes made in plant nutrition. A different reaction of the studied cauliflower varieties to the usability features under analysis, manifesting itself in the domination of the white variety over the other two types, also confirmed in previous studies (Cebula et al. 2005), might have resulted from individual features of each variety. However, breeding studies for particular cultivars are carried out in a different way. White cauliflower is the oldest of all known types, still undergoing improvements and in the course of many years of experiments new, well-tested cultivars were developed. Green and romanesco cauliflowers have been cultivated for a short time and the number of cultivars is limited. Hopefully, the continuous advancement in breeding will allow developing cultivars of a quality comparable to the white cauliflower.

\section{CONCLUSIONS}

1. Fresh mass of overground part and root system of transplants ready for planting in case of all cauliflower types were considerably higher from older plants, grown in pots of larger volume. Such dependence was not confirmed when assessing dry matter content.

2. The commercial yield and the average curd weight were highest for white type cauliflower, lower for green variety and the lowest for romanesco type. All three types achieved their maximal values with the older transplant and bigger pot size.

3. Most curds of grade I, of the largest diameter (class A) were determined for white cauliflower, slightly fewer those of green type, and the fewest of romanesco variety, cultivated from older transplants and with larger root system.

4. Particular cauliflower forms differed quite appreciably in respect to their tendency to form curd defects (green bracts, hollow stems, riciness, and browning). The least susceptible to disorder in curd formation was white cauliflower with romanesco being the most sensitive type.

\section{REFERENCES}

Booij R. 1990. Influence of transplant size and raising temperature on cauliflower curd weight. Gartenbauwis. 55(3): 103-109.

Cebula S., Kalisz A., Kunicki E. 2005. [The effect of growing term on yielding and commercial quality of white, green and romanesco cauliflower curds]. Zesz. Nauk. AR we Wrocławiu, Rolnictwo LXXXVI (515): 69-76. [in Polish with English summary]

Damato G., Trotta L., Elia A. 1994. Cell size, transplant age and cultivars effects on timing field production of broccoli (Brassica oleracea L. italica Plenck) for processing. Acta Hort. 371: 53-60. 
Godoy M.C., Cardoso A.I.I. 2005. [Cauliflower production depending on age of seedling and cell size of trays]. Hortic. Bras. 23 (3): 837-840. [in Portuguese with English summary]

Grevsen K., Olesen J.E. 1994. Modelling development and quality of cauliflower. Acta Hort. 371: 151-160.

Grevsen K., Olesen J.E., Veierskov B. 2003. The effects of temperature and plant developmental stage on the occurrence of curd quality defects "bracting" and "riciness" in cauliflower. J. Hort. Sci. Biotech. 78 (5): 638-646.

Lamont W.J. 1992. Transplant age has little effect on broccoli head weight and diameter. HortSci. 27 (7): 848.

Lewandowska A. 1992. [The influence of transplant age on the yield of three cultivars of cauliflower in summer]. Biul. Warz. XXXIX: 37-49. [in Polish with English summary]

NeSmith D.S., Duval J.R. 1998. The effect of container size. HortTech. 8 (4): 495-498.

Vavrina C.S. 1998. Transplant age in vegetable crops. HortTech. 8 (4): 550-555.

Wiebe H.J. 1981. Influence of transplant characteristics and growing conditions on curd size (buttoning) of cauliflower. Acta Hort. 122: 99-105.

Wurr D.C.E., Cox E.F., Fellows J.R. 1986. The influence of transplant age and nutrient feeding regime on cauliflower growth and maturity. J. Hort. Sci. 61: 503-508.

\section{WPŁYW WIELKOŚCI DONICZEK I WIEKU ROZSADY NA PLONOWANIE I JAKOŚĆ RÓŻ KALAFIORA BIAŁEGO, ZIELONEGO I ROMANESCO}

\section{Streszczenie}

Przedmiotem badań był kalafior o różach białych odmiany Planita $F_{1}$, zielonych Trevi $F_{1}$ i romanesco Amfora $F_{1}$, uprawiany $z$ rozsady o zróżnicowanym wieku (około 30 i 40 dni) oraz przygotowanej w różnej wielkości doniczkach (96 i 160 komórek/paletę). Określono parametry rozsady gotowej do sadzenia, oszacowano poziom plonowania oraz jakość handlową róż. Świeża masa części nadziemnej i systemu korzeniowego rozsady u wszystkich form kalafiora była zdecydowanie wyższa u rozsady starszej oraz z doniczek o większej objętości. Wielkość plonu handlowego oraz średnia masa róż była najwyższa u kalafiora białego, niższa u zielonego, a najniższa u romanesco. Wszystkie trzy formy kalafiora osiągnęły maksymalne wartości plonu i masy róż w obiektach ze starszą rozsadą i większymi doniczkami. Więcej róż I wyboru, o największej średnicy, wykształciły rośliny kalafiora białego, nieco mniej zielonego i wyraźnie mniej romanesco. U wszystkich trzech rodzajów kalafiora, rośliny uprawiane z rozsady starszej i posiadające większą bryłę korzeniową, zapewniły uzyskanie róż o najkorzystniejszych walorach handlowych. Poszczególne formy kalafiora różniły się dość istotnie skłonnością do występowania zaburzeń w rozwoju róż (przerośnięcie liśćmi, jamistość głąba, omszenie, zbrunatnienie). Najmniej podatnym na powstawanie zaburzeń w rozwoju róż był kalafior biały, a najbardziej wrażliwy romanesco. U kalafiora białego rozsada uzyskana z mniejszych doniczek, zwłaszcza młodsza, spowodowała zwiększenie liczby róż z zaburzeniami, natomiast u zielonego i romanesco rozsada wyprodukowana w większych doniczkach, szczególnie bardziej zaawansowana wiekiem, decydowała o wystąpieniu większej ilości róż z wadami. 